\title{
Discussion on Curriculum Provision of International Trade Major under the Background of Transition
}

\author{
Tong Mei \\ College of Science and Technology \\ Nanchang University \\ Nanchang, Jiangxi, China
}

\author{
Jiling Chen \\ College of Science and Technology \\ Nanchang University \\ Nanchang, Jiangxi, China
}

\author{
Mingmin Chen \\ College of Science and Technology \\ Nanchang University \\ Nanchang, Jiangxi, China
}

\begin{abstract}
Under the background that common regular colleges transit to application-oriented technical universities, universities must carry out corresponding innovation and reform of curriculum, build teaching class focusing on training applied technical ability and improve the quality of teaching. In class, teachers shall take effective teaching methods, improve quality and effect of classroom teaching to some extent and enhance students' manipulative ability.
\end{abstract}

Keywords - transition; international trade major; curriculum provision

\section{BACKGROUND THAT UNDERGRADUATE COLLEGES TRANSIT TO APPLICATION-ORIENTED TECHNICAL UNIVERSITIES}

Lu Xin, the deputy minister of Ministry of Education revealed on "China Development Forum" in March 22, 2014 that local undergraduate colleges will gradually transit to modern professional education. On training pattern, it will weaken disciplines and strengthen majors and cultivate technical and skilled talents. There are nearly 2,500 institutions of higher learning in China. After the reform is finished, there will be more than 1,600 to 1,700 schools centering on vocational and technical education. For international trade major, transformation development needs to further reform and innovate in talent training pattern, reform major courses and pay attention to cultivating application-oriented technical talents.

\section{OBJECTIVE OF APPLICATION-ORIENTED TECHNICAL TALENTS TRAINING IN INTERNATIONAL TRADE MAJOR}

Application-oriented technical talents refer to trained talents who can apply specialized theoretical knowledge and application skills to working practice that they engage in, as well as technical talents or professional talents who skillfully grasp basic knowledge and basic skills of related majors and mainly work on frontline of first-line production. Its specific

This thesis refers to the educational plan task in 2015 of the 12th FiveYear Plan of Jiangxi province, "Research on Transformation of Independent College-from the Perspective of Professional Education", project number 15 YB189. connotations develop continuously with the development of higher education. In 2010, the Outline of the National Medium and Long-term Educational Reform and Development Plan pointed out higher education shall "pay attention to enlarging the scale of applied, compound and skilled talents training". In 2012, the Ministry of Education of our country put forward in Some Opinions on Comprehensively Improving the Quality of Higher Education, "taking promotion of all-round development of human being and adaptation of social needs as basic standards to measure the level of talent training".

To sum up, the objective of applied talent training of international trade major: to cultivate applied international business talents with international view, innovative and pioneering spirit who can meet the requirements of economic and social development of our country, have related basic theoretical knowledge and applied practical skills of international trade, thoroughly understand the latest operating model of international trade service and basic operational skills and expertly use English to communicate.

\section{MAIN PROBlems EXISTING IN COURSE SYSTEM} CONSTRUCTION OF CURRENT INTERNATIONAL TRADE MAJOR

Course system refers to the knowledge system carried out by permutation and combination of relevant subject knowledge and practical links according to certain proportion and logic sequencing as well as certain specialized talent training objective. Course system construction shall firstly embody requirements and standards of this major, reflect characteristics of subject, have certain flexibility and meet all-around market demand for talents of international trade major and also embody economic characteristics of the school and this region. At present, problems existing in course system construction of international trade major mainly include:

\section{A. The Goalfor Major Training Has Incorrect Positioning and the Setting of Course System Is Unscientific}

Influenced by traditional education model, at present, the teaching orientation of ordinary colleges pays too much 
attention to theoretical knowledge in general. They are inclined to cultivate students into talents with theoretical knowledge, lacking practice application ability. This teaching orientation has been unable to adapt to the current national training requirements and modern international trade situation. When deflection of positioning of training goals is reflected in cultivation process, it appears the tendency on course system construction. That is to say, on curriculum provision, they still adopt the traditional discipline-based education model, mainly consider from discipline system and focus on specialized discipline curriculum and lack comprehensive theory and practice course. The unique features of education are not obvious. They attach excessive importance to theoretical knowledge and specialized knowledge and seldom take comprehensive knowledge and practical knowledge required by students in the future employment into consideration. To thoroughly change this situation, it is necessary to reform from teaching orientation, teaching model, teaching system, teaching content, teaching method and teaching means, change discipline-based education into competency-based education and effective solve the problem that students cannot apply their knowledge.

\section{B. The Quantity of Course and Class Hours Is Too Big and the Course Structure Is Unreasonable}

Reflecting ambiguous location of training objective on course system, it shows: On curriculum provision, they bite off more than they can chew. It is difficult for them to handle the relationship between theoretical courses and practice courses as well as between major required courses and major selective courses. Besides, major courses are opened mainly in the third year and fourth year. Students have to finish the learning of most major courses in three semesters. Students have heavy learning burden, are tired of it, resulting in poor learning effects. The teaching contents of some courses are antiquated with slow speed of updating and fail to keep pace with the situation of international trade development.

\section{Contents between Different Courses Cross and Course Contents Are Seriously Repeated}

At present, the curriculum provision of international trade major between different universities is not unified. The course setting has certain subjectivity, which cause the phenomenon that the contents between different courses cross. For example, some content of "letter of credit" is the key point of teaching contents of the whole international trade major, but it appears repeatedly in many courses such as International Trade Affairs, Foreign Trade Documents and Certificate, Foreign Business Correspondence, Foreign Trade Documentary Practice and International Clearing. Another example, "international cargo transportation" is introduced in International Trade Affairs, International Freight Forwarder and Custom Practice. It leads to the situation that course teachers engage at will and teach theoretical contents of this part for many times, but in actual operation, students still cannot apply it and be competent for actual work of employers. This kind of curriculum provision will waste limited teaching resources and go against the cultivation of students' ability and interest.

\section{Pay Attention to Theory and Think Little of Practice, and the Proportion of Practice Course Is Unreasonable}

The practice teaching link of local undergraduate universities mainly shows in the following forms: The first is the hour of practice course. Serve as extension and strengthening of theoretical teaching in class, focus on practice in teaching class, with short time. The second is practice course, independently existing by separating from certain theoretical course. It is often set in one semester or several weeks. The third is comprehensive graduation practice, such as graduation practice and graduation design. Because of particular characteristics of international trade major, students' practical activities can only be carried out on campus by adopting simulation software and simulative scenes. Students cannot practice with real customers, products and orders. Under this condition, the practice teaching link for students cannot reach the anticipated effect. It is difficult to train their "application ability".

\section{MEASURES TO QUiCKEN COURSE SYSTEM CONSTRUCTION OF INTERNATIONAL TRADE MAJOR}

\section{A. Reasonably Set Cultivation Standard of Professional Talents}

For a long time, the training objective of international trade major is wraparound. We should first solve the problem about how to detail it and reasonably formulate talent cultivation standard in international trade major. Application-oriented universities mainly cultivate professional skilled talents for enterprises. Therefore, setting talent cultivation standard should base on requirements of employers. When formulating applied talent cultivation standard, it is necessary to fully highlight the importance of professional skills and have clear requirements for students of international trade major on the ability to communicate with foreign languages, foreign trade business operation ability, international etiquette as well as communication and coordination ability.

\section{B. Improve Course System of International Trade Major}

The setting of courses such as general-knowledge course, professional basic course and professional main course should be adjusted according to characteristics of students and requirements of professional skills. In teaching plan of 2010 edition of international trade major of our school, the percentage of class hour and credit hour is as follows "Table I".

TABLE I. COURSE System of International Trade Major

\begin{tabular}{|l|l|l|}
\hline \multicolumn{1}{|c|}{ Course type } & \multicolumn{1}{c|}{ Credit } & Percentage \\
\hline General-knowledge course & 42 & $25.61 \%$ \\
\hline Professional basic course & 53.5 & $32.62 \%$ \\
\hline Professional main course & 32 & $19.51 \%$ \\
\hline Professional selective course & 28.5 & $17.38 \%$ \\
\hline Optional courses of quality and ability & 8 & $4.88 \%$ \\
\hline Total & 164 & $100 \%$ \\
\hline
\end{tabular}

Firstly, "general-knowledge course" shall include some basic courses, in order to train students' knowledge-based view and view of price. Professional basic courses shall include some courses that have close relationship with this major, such as "Western Economics", "Accounting" and "Statistics". 
Although they are theoretical courses, it greatly helps students to establish basic economic concept and improve their comprehensive ability and analytical ability for this major. "Professional main courses" include theoretical courses and practical applied courses. It is necessary to allocate the proportion of them to let students understand and grasp essential theoretical knowledge and train related professional skills. "Professional selective courses" shall include extended courses related to international trade major and adjust according to relevant situation of the current international trade. Optional courses of quality and ability means that students select courses according to their interest and hobbies. There are teaching arrangements in professional basic courses and main courses for practice courses. There are only 20 credits, accounting for $12 \%$ of the total credit. They should increase the proportion of credit in practice courses.

\section{Optimize Contents of Major Courses}

Courses in international trade major have high degree of specialization and close relationship, but many courses are repeated. Teachers should communicate with each other and tease the repeated contents between courses. They shall focus on teaching some courses and briefly teach or neglect to teach some courses, avoid repetitive learning. Besides, according to current situation and characteristics of students, universities can organize teachers of different majors to compile textbook of different majors and unify textbook content to avoid repeated contents.

\section{Increase the Proportion of Practical Teaching}

Applied talent training shall focus on letting students grasp professional knowledge and skills required by employment directly and pay attention to proportion of theoretical teaching and practical teaching. Let students grasp theoretical knowledge and have professional skills and can be employed at once after graduation. These practical abilities can be trained through training platform on campus and off-campus practice platform, professional software simulation, participating in professional competition, visiting foreign trade enterprises, short-term internship in enterprises and graduation practice, so universities can cultivate applied professional talents with theoretical knowledge of foreign trade in university campus.

All in all, under the background that common regular colleges transit to application-oriented technical universities, it is the main task of international trade major to cultivate foreign trade business talents with basic accomplishment of foreign trade theory and actual operating skill of foreign trade business. Only through basing on the requirements of foreign trade enterprises, taking scientific educational concept as the guidance and continuously optimizing professional talent training pattern can they truly cultivate high-level applied foreign trade talents and provide strong guarantee of talents for our country to unceasingly develop international trade.

\section{REFERENCES}

[1] Mei Tong. Application of Case Teaching Method in Teaching of International Trade Affairs Course, Foreign Trade, 2014, (8): 42-43
[2] Hu Zhongying, Yu Maohui. Discussion on Curriculum System Reform of International Trade Major in Applied Undergraduate Universities [J], Journal of Tongling, College, 2010, (6): 100-101

[3] Mei Tong. Exploration on Talents Training Mode of International Trade Major under the Background of Transiting to Application-oriented Technical Universities [J], Foreign Trade, 2016, (5): 131-132

[4] Su Hang. Research on Talent Training Reform in International Trade Major in Independent Colleges-Take College of Humanities and Information, Changchun University of Technology as an Example [J], Times Finance, 2013 (10): 55-56

[5] Liang Jiahui. Research on Construction of Applied Undergraduate Talents Training Mode in Specialty of International Economy and Trade [J], the Science Education Article Collects, 2014, (7): 66-67

[6] Li Yu. Research on Curriculum System Design in Specialty of International Economy and Trade [J], Business Economics, 2010, (2): $111-112$ 